\title{
Endo-perio lesions prevalence in non-molar and molar teeth: a pilot study
}

\author{
Prevalência de lesões endo-perio em dentes não-molares e molares: um \\ estudo piloto
}

\author{
Flávia Cristina Castilho CUCOLO ${ }^{\mathrm{a}}\left[\right.$, Mariana Costa BONVALENTEb $^{\mathrm{b}}$, Eliane Marçon BARROSO ${ }^{(1)}$, \\ Benedicto Egbert Corrêa de TOLEDO' (in memorian), \\ Gabriela Alessandra da Cruz Galhardo CAMARGO ${ }^{\text {b,d }}{ }^{(D)}$, Alessandra Areas e SOUZA ${ }^{d}$ (iD, \\ Elizangela Cruvinel ZUZA ${ }^{\mathrm{b}, \mathrm{d} *}$ (1) \\ aUNIFEB - Centro Universitário da Fundação Educacional de Barretos, Departamento de Odontologia, Barretos, SP, \\ Brasil \\ bUFF - Universidade Federal Fluminense, Instituto de Saúde de Nova Friburgo, Programa de Pós-graduação em \\ Odontologia, Nova Friburgo, RJ, Brasil \\ "UNESP - Universidade Estadual Paulista "Júlio de Mesquita Filho", Faculdade de Odontologia, Departamento de \\ Diagnóstico e Cirurgia, Araraquara, SP, Brasil \\ dUFF - Universidade Federal Fluminense, Instituto de Saúde de Nova Friburgo, Departamento de Formação Específica, \\ Nova Friburgo, RJ, Brasil
}

\author{
How to cite: Cucolo FCC, Bonvalente MC, Barroso EM, Toledo BEC, Camargo GACG, Souza AA, et al. Endo-perio lesions \\ prevalence in non-molar and molar teeth: a pilot study. Rev Odontol UNESP. 2021;50:e20210037. \\ https://doi.org/10.1590/1807-2577.03721
}

\begin{abstract}
Resumo
Introdução: Os tecidos pulpar e periodontal podem se comunicar e, em situações patológicas, podem-se estabelecer lesões endodônticas-periodontais combinadas. Objetivo: 0 objetivo deste estudo foi avaliar a prevalência de lesões endo-perio em dentes não molares e molares encaminhados para tratamento endodôntico. Material e método: A amostra consistiu de 104 dentes avaliados em 79 pacientes consecutivos em um desenho transversal. Placa visível, profundidade de sondagem e sangramento à sondagem foram avaliados. A avaliação endodôntica incluiu a presença ou ausência de cáries, fístulas, dor e sensibilidade pulpar. Foram avaliados a presença / ausência de lesão periapical, perda óssea em região de furca e área proximal. Resultado: Os resultados mostraram que a dor foi o principal motivo de procura de atendimento odontológico em $63,3 \%$ dos pacientes. Os dentes molares demonstraram maior presença de profundidade de sondagem (PS) $\geq 7 \mathrm{~mm}(38,3 \%)$ e maior média de PS $(6,17 \mathrm{~mm})$ do que os dentes não molares ( $\mathrm{P}<0,05)$. Verificou-se que $65,4 \%$ dos dentes tinham diagnóstico de lesão endodôntica primária e que o componente periodontal estava presente em 34,6\% dos dentes, seja na forma primária (10,6\%), secundária $(11,5 \%)$ ou combinada (12,5\%). Lesão endodôntica-periodontal combinada verdadeira ocorreu significativamente em dentes molares em comparação com os dentes não molares $(p<0,05)$. Conclusão: A lesão endodôntica primária foi encontrada em maior proporção nos dentes encaminhados para tratamento endodôntico; entretanto, aproximadamente 1/3 da amostra apresentava acometimento periodontal, o que demonstra a importância do exame periodontal em conjunto com o exame clínico geral.
\end{abstract}

Descritores: Doenças da polpa dentária; diagnóstico; endodontia; periodontia; estudos transversais; doenças periodontais.

\begin{abstract}
Introduction: Pulp and periodontal tissues may communicate and, in pathological situations, combined endodontic-periodontal lesions may be established. Objective: The aim of this study was to evaluate the prevalence of endo-perio lesions in non-molar and molar teeth referred for endodontic treatment. Material and method: The sample consisted of 104 teeth evaluated in 79 consecutive patients in a cross-sectional design. Visible plaque, probing depth, and bleeding on probing were evaluated. Endodontic evaluation included the presence or absence of caries, fistulas, pain, and pulp sensitivity. The presence/absence of periapical lesion, bone loss in the furcation region, and proximal area were evaluated. Result: The results
\end{abstract}


showed that pain was the main reason for seeking dental care in $63.3 \%$ of patients. The molar teeth demonstrated higher presence of probing depth (PD) $\geq 7 \mathrm{~mm}(38.3 \%)$ and higher PD mean (6.17 $\mathrm{mm})$ than non-molar teeth $(\mathrm{P}<0.05)$. It was verified that $65.4 \%$ of the teeth were diagnosed with a primary endodontic lesion and that the periodontal component was present in $34.6 \%$ of the teeth, either in a primary $(10.6 \%)$, secondary (11.5\%), or combined form (12.5\%). True combined endodontic-periodontal lesion occurred significantly in molar teeth compared to non-molar teeth $(\mathrm{p}<0.05)$. Conclusion: The primary endodontic lesion was found in a greater proportion in teeth referred for endodontic treatment; however, approximately $1 / 3$ of the sample had periodontal involvement, which demonstrates the importance of the periodontal examination together with the general clinical examination.

Descriptors: Dental pulp diseases; diagnosis; endodontics; periodontics; cross-sectional studies; periodontal diseases.

\section{INTRODUCTION}

Endodontic-periodontal lesions are included in the category of other conditions that affect the periodontium by the new classification of the American Academy of Periodontology and the European Federation of Periodontology ${ }^{1}$. Several other classifications have been proposed to date $^{2-5}$, of which the classification by Simon et al.2,4 is the most widely used to identify etiologic factors, addressing different clinical conditions that consider the primary cause of the disease, such as the presence of a primary endodontic lesion; primary endodontic lesion with secondary periodontal involvement; primary periodontal lesion; primary periodontal lesion with secondary endodontic involvement; and true combined lesion ${ }^{5}$.

In the case of isolated endodontic and periodontal lesions, the diagnosis can be established, in most cases, without much difficulty, considering the clinical and radiographic signs, however, in certain situations in which a tooth is affected by pulp and periodontal disease, concomitantly, the clinical signs are not as clear because the clinical aspects are confused ${ }^{6}$. Regarding endodontic/periodontal primary and secondary involvement and true combined lesions, the radiographic aspects may also be confused since they are very similart ${ }^{4}$. however, the diagnosis can be facilitated if the patient has been monitored for some time and retrospective radiographs are available ${ }^{7}$.

Some results have shown that the clinical involvement of the dental pulp with a negative response to sensitivity tests occurs only when periodontitis reaches the major apical foramen, on the other hand, it should be taken into account that the pulp-periodontal communication pathway occurs not only through the major foramen, but also through the dentinal tubules ${ }^{9}$, accessory canals ${ }^{10}$, and canals located in the roof of the furcation in multiradicular teeth ${ }^{11}$.

The molars are considered the teeth with the most doubtful prognosis when periodontitis is established and progresses, due to the presence of furcation defects, concavities, root trunk height, divergence between the roots, and being in a more posterior position in the $\operatorname{arch}^{12}$. Some authors have demonstrated that when molar teeth were compared to non-molar teeth, they presented higher plaque indexes and increased probing depth and clinical attachment level ${ }^{13}$. There is still a lack of clinical studies regarding the aspects of endodontic-periodontal lesions in molar and non-molar teeth. Given these considerations, the objective of this study was to perform a periodontal evaluation on single-rooted and multiradicular teeth, referred for endodontic treatment, in order to assess the prevalence of periodontitis involvement in these teeth and to verify the relationship of endoperiodontal lesions.

\section{MATERIAL AND METHOD}

This study was approved by the Research Ethics Committee of the Barretos Educational Foundation University Center, under protocol 883.469/2014. The study was explained to the participants, any questions were answered, and individuals were included in the research only after signing a free and informed consent form. 


\section{Study Design and Sample}

The current pilot study presented a cross-sectional observational design, with the participation of 79 consecutive patients of both genders, referred for endodontic treatment at the Endodontics Clinics of the School of Dentistry of the Barretos Educational Foundation University Center (UNIFEB). One patient could contribute more than one dental element to the analyses. A total of 104 teeth were evaluated, 57 single-rooted teeth and 47 multi-rooted teeth. Patients who reported prior periodontal treatment and/or orthodontic treatment in the previous year were excluded, as well as those who reported diabetes mellitus, rheumatoid arthritis, smoking, or any chronic inflammatory disease. The first premolars were excluded from the study due to the possibility of having two roots in approximately $40 \%$ of cases, with no plausible possibility of assessing the furcation region located in the apical third*. Teeth with endodontic treatment or with indication for retreatment were also excluded to avoid confusion with vertical root fracture.

\section{Calibration}

All examinations were performed by one calibrated examiner. Prior to the start of the study, 10 patients who were referred for endodontic treatment were evaluated for the purposes of evaluator training and calibration (FCCC) and were not included in the final sample. For this purpose, each patient contributed with only one tooth. The evaluator was calibrated regarding the application of the cold sensitivity test on the same elements, with a five-minute interval between applications. Categorical data were calculated by the Kappa test, obtaining a value of 0.9038 , which demonstrated excellent replicability $(\mathrm{p}<0.0001)$. Another examiner (ECZ) was calibrated for periodontal measurements. Probing depth was used for periodontal calibration, performed at six points of each tooth, in duplicate, with an interval of five minutes. Agreement between measurements was verified by the intraclass correlation test (CI) for continuous data, which demonstrated excellent replicability $(\mathrm{CI}=0.9148 ; \mathrm{p}<0.0001)$. Data were analyzed using BioEstat Software, version 5.0 (Mamirauá Institute, Belém, Brazil).

\section{Periodontal Evaluation}

For periodontal clinical examination, a PCPUNC15 North Carolina-type periodontal probe (HuFriedy ${ }^{\circledR}$, Chicago, USA) and flat mirror were used under reflector light and dry field. Data were noted on data collection forms. The following clinical periodontal parameters were evaluated: a) visible plaque index (VPI): after drying with air jets, the presence of visible microbial deposits was visually evaluated in the dental crown, being characterized as present or absent14; b) probing depth (PD): the distance between the free gingival margin and the bottom of the gingival sulcus or periodontal pocket ${ }^{15}$. The PD was performed at six sites per tooth, at three points per buccal (mesial, medial, and distal) and at three points per lingual/palatal (mesial, medial, and distal), and only the deepest PD was noted; c) bleeding on probing (BOP): recorded as present or absent until 30 seconds after probing ${ }^{15}$. A Nabers periodontal probe was used to measure the increase in the horizontal probing depth to verify the horizontal attachment loss, which was considered as present or absent.

\section{Endodontic Evaluation}

Pulp status was determined by applying the cold test through the method adopted by Neves et al. ${ }^{8}$ For the application of the cold stimulus test, we used the Endo-Frost ${ }^{\circledR}$ (ROEKO, P.O. Box 1150, Langenau, Germany). The tooth was isolated with cotton rollers and the surface of the tooth crown was then dried.

*Lang NP, Lindhe J. Clinical periodontology and implant dentistry. Hoboken: Wiley-Blackwell; 2018. 
The Endo-Frost ${ }^{\circledR}$ was applied at the midpoint of the cervical third of the anatomical crown of the tooth, using a cotton ball saturated with refrigerant gas (activated by valve pressure for approximately 3 seconds). To eliminate individual variation in sensitivity, the test was repeated on a homologous sound tooth. The stimulus was maintained considering the immediate response of the tooth or for up to 10 seconds after.

In the teeth that did not respond to the cold test twice, the test cavity was then performed. Diamond spherical tips were used in a 1014/1019 KG Sorensen ${ }^{\circledR}$ (Medical Burs Ind. e Com. de Pontas e Brocas Cirúrgicas Ltda., Cotia, Brazil) to coronal access.

Caries and restorations were evaluated during the clinical examination of the dental element and noted as present or absent. The opening of fistulas was clinically observed, being considered as present or absent.

\section{Radiographic Evaluation}

Periapical radiographs were performed through the parallelism technique using the radiographic positioner (Indusbello ${ }^{\circledR}$, Londrina, Brazil). Prior endodontic treatment, the presence or absence of periapical pathology and proximal bone loss in all molar and non-molar teeth were evaluated. The presence/absence of furcation bone rarefaction was evaluated only in molars. Proximal bone loss, measured on the mesial and distal surfaces with a millimeter endodontic ruler on a negatoscope was considered present or absent. Bone loss was considered present when the distance between the cemento-enamel junction and the alveolar bone crest was $>2 \mathrm{~mm}^{16,17}$.

\section{Classification Adopted for Case Analysis}

Data were collected and analyzed to determine the diagnosis of the lesion, according to the classification by Simon et al.2,4. in: 1) Primary endodontic lesion; 2) Primary endodontic lesion with secondary periodontal involvement; 3) Primary periodontal lesion; 4) Primary periodontal lesion with secondary endodontic involvement; and 5) True combined lesion.

a) Primary endodontic lesion: the pulp may present abnormal responses or, generally, be necrotic, not responding to thermal or electrical tests. In some cases, the fistula could draining through the periodontal ligament with appearance of a narrow periodontal pocket (in one site of the tooth) or even in the furcation region; however, the presence of periodontal disease was excluded when the levels of the mesial and distal bone ridges are at normal height;

b) Primary endodontic lesion with secondary periodontal involvement: occurs if the endodontic problem remains untreated and leads to involvement of the periodontal structures. In this case, biofilm and calculus begin to accumulate in the marginal gums, progressing over time and leading to signs of periodontitis (periodontal pocket, bleeding on probing, alveolar bone loss) together with the endodontic commitment;

c) Primary periodontal lesion: the pulp responds with normal sensitivity or symptomatic reversible pulpitis, but no necrosis is identified. Periodontitis progresses along the root and can reach the dental apex. Biofilm/calculus and bleeding on probing are present and sites with probing depth higher than $6 \mathrm{~mm}(\mathrm{PD} \geq 6 \mathrm{~mm})$ are common in more than one site of the tooth. Larger periodontal pocket extension and alveolar bone loss are common signs;

d) Primary periodontal lesion with secondary endodontic involvement: with the progression of periodontitis ( $\mathrm{PD} \geq 6 \mathrm{~mm}$, bleeding on probing, alveolar bone loss), accessory or lateral canals or involvement of the apical foramen may lead to pulp necrosis. The pulp sensitivity responds negatively; 
e) True combined lesion: There is a unique lesion in the radiographic image. Clinical and radiographic aspects are indistinguishable from the two lesions that are involved secondarily because there are pulp necrosis and general signs of periodontitis.

\section{Statistical Analysis}

Descriptive data analysis was performed for the general characteristics of the sample. Means and standard deviations were calculated for continuous variables and frequency tables for categorical variables. Clinical characteristics of the teeth were evaluated with the binomial test for two independent samples, when comparing the sample between molar and non-molar teeth. In the case of bone rarefaction in the furcation region only in molar teeth, a binomial test for one sample was evaluated. For comparison of the mean probing depths, the Mann-Whitney test for nonparametric data was used. The evaluation between pulp sensitivity and the characteristics of proximal bone loss, furcation bone rarefaction, and periapical pathology were evaluated by the Fisher's exact test. The relationship between pulp sensitivity and probing depth was analyzed by the Chi-square test. A statistical significance of 0.05 was considered and the data were analyzed using BioEstat Software, version 5.0 (Instituto Mamirauá, Belém, Brazil).

\section{Sample Power Calculation}

No similar study was found; therefore, a sample size was calculated based on sites with deep PD mean in between molars $(6.17 \mathrm{~mm})$ and non-molars $(4.29 \mathrm{~mm})$. Power was detected by difference between two independent means (two groups) by Pos hoc: computed achieved power (Gpower 3.1.9.6, Franz Faul, Universintäl Kiel, Germany). Difference in PD was 1.88 among molars and no-molars teeth, with $\alpha<0.05,47$ teeth in each experimental group were needed.

\section{RESULT}

The general characteristics of the sample can be seen in Table 1. The mean age was 41.66 years, with females being the most prevalent (68.4\%). Pain was the main reason for seeking dental care (63.3\%). Of the sample, 6.3\% reported having problems with dental mobility and $44.3 \%$ had a bad breath in their mouth. Gingival bleeding was self-reported by $50.6 \%$ of the patients and $91.1 \%$ had never received periodontal treatment.

Table 2 presents the clinical characteristics of the evaluated teeth. Molar teeth presented higher presence of probing depth (PS) $\geq 7 \mathrm{~mm}(38.3 \%)$, and higher mean PD $(6.17 \mathrm{~mm})$ than nonmolar teeth $(\mathrm{P}<0.05)$. Pulp sensitivity was present in 45 teeth, while 59 teeth showed no pulp sensitivity, without statistical difference between non-molar and molar teeth $(\mathrm{P}>0.05)$.

Table 3 shows the frequency and diagnosis of the type of endoperiodontal lesion in the total sample $(n=104)$. It was found that $65.4 \%$ of the teeth were diagnosed with primary endodontic lesion, and that periodontal lesions were present in $34.6 \%$ of the teeth, either as secondary $(11.5 \%)$, primary $(10.6 \%)$, or combined $(12.5 \%)$. The results demonstrated that true endodonticperiodontal combined lesion occurred more frequently in molar teeth when compared to nonmolar teeth $(\mathrm{p}<0.05)$.

The relationship between clinical characteristics and pulp sensitivity can be seen in Table 4. A statistically significant relationship was found between the presence of periapical pathology and absence of pulp sensitivity ( $\mathrm{p}<0.05$ ). Thus, we can present the following reasoning: $49 \%$ of teeth with periapical pathology and without pulp sensitivity presented necrosis. The absence of periapical pathology, viewed radiographically, together with the absence of pulp sensitivity, occurred in $14.5 \%$ of the teeth, which features a clinical situation of necrosis. Regarding bone 
rarefaction in the furcation region of the molar teeth, it was found that $31.9 \%$ of the sample presented negative pulp sensitivity and furcation rarefaction, without increasing the horizontal probing depth, which is consistent with endodontic lesion without periodontal involvement.

Table 1. General characteristics of the sample in the study

\begin{tabular}{cccc}
\hline Variable & Mean (Standard Deviation) & $\begin{array}{c}\text { Frequency } \\
\text { n (\%) }\end{array}$ \\
\hline Age (years) & $41.66(14.14)$ & & \\
Sex & & 54 & $(68.4)$ \\
Female & 25 & $(31.6)$ \\
Male & & \\
Reason for dental treatment & 50 & $(63.3)$ \\
Pain & 7 & $(8.9)$ \\
Fracture & 5 & $(6.3)$ \\
Dental mobility & 17 & $(21.5)$ \\
Other causes* & & \\
Self-reported bad breath & 44 & $(55.7)$ \\
No & 35 & $(44.3)$ \\
Yes & & \\
Nelf-reported gingival bleeding & 39 & $(49.4)$ \\
Nos & 40 & $(50.6)$ \\
Prior periodontal treatment & & \\
No & 72 & $(91.1)$ \\
Yes & 7 & $(8.9)$ \\
\hline
\end{tabular}

*Abscess, cavity, dark tooth, sensitive tooth, prosthetic purpose, fistula, orthodontic indication, trauma, cervical dentinal hypersensitivity.

Table 2. Clinical characteristics of the teeth evaluated in the study

\begin{tabular}{|c|c|c|c|c|}
\hline Clinical characteristics & $\begin{array}{c}\text { Non-molar teeth } \\
(n=57)\end{array}$ & $\begin{array}{c}\begin{array}{c}\text { Molar teeth } \\
(n=47)\end{array} \\
\end{array}$ & $P$ value & $\begin{array}{c}\text { Total teeth } \\
(\mathrm{n}=104)\end{array}$ \\
\hline \multicolumn{5}{|l|}{ Caries/Restorations $-n(\%)^{\ddagger}$} \\
\hline Yes & $55(96.5)$ & $42(89.4)$ & 0.1487 & $97(93.3)$ \\
\hline No & $2(3.5)$ & $5(10.6)$ & & $7(6.7)$ \\
\hline \multicolumn{5}{|c|}{ Prior endodontic treatment $-n(\%) \neq$} \\
\hline Yes & $0(0.0)$ & $0(0.0)$ & 0.6754 & $0(0.0)$ \\
\hline No & $57(100)$ & $47(100)$ & & $104(100.0)$ \\
\hline \multicolumn{5}{|l|}{ Presence of fistulas $-n(\%)^{\ddagger}$} \\
\hline Yes & $12(21)$ & $8(17)$ & 0.6037 & $20(19.2)$ \\
\hline No & $45(79)$ & 39 (83) & & $84(80.8)$ \\
\hline \multicolumn{5}{|l|}{ Visible plaque $-n(\%)^{\ddagger}$} \\
\hline Yes & $37(64.9)$ & $31(66)$ & 0.9112 & $68(65.4)$ \\
\hline No & $20(35.1)$ & $16(34)$ & & $36(34.6)$ \\
\hline \multicolumn{5}{|l|}{ Bleeding on probing $-n(\%)^{\neq}$} \\
\hline Yes & $39(68.4)$ & $32(68.1)$ & 0.9708 & $71(68.3)$ \\
\hline No & $18(31.6)$ & $15(31.9)$ & & 33 (31.7) \\
\hline \multicolumn{5}{|l|}{ Proximal bone loss $-n(\%)^{\ddagger}$} \\
\hline Yes & $25(43.9)$ & $24(51.1)$ & 0.4639 & $49(47.1)$ \\
\hline No & $32(56.1)$ & $23(48.9)$ & & $55(52.9)$ \\
\hline \multicolumn{5}{|c|}{ Furcation bone rarefaction $-n(\%)^{\alpha}$} \\
\hline Yes & 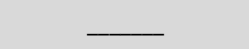 & $17(36.2)$ & 0.9814 & - \\
\hline No & & $30(63.8)$ & & \\
\hline
\end{tabular}


Table 2. Continued...

\begin{tabular}{|c|c|c|c|c|}
\hline Clinical characteristics & $\begin{array}{c}\text { Non-molar teeth } \\
(n=57)\end{array}$ & $\begin{array}{c}\text { Molar teeth } \\
(n=47)\end{array}$ & $P$ value & $\begin{array}{c}\text { Total teeth } \\
(\mathrm{n}=104)\end{array}$ \\
\hline \multicolumn{5}{|l|}{ Periapical pathology $-n(\%)^{\ddagger}$} \\
\hline Yes & $26(45.6)$ & $27(57.45)$ & 0.2296 & $53(51.0)$ \\
\hline No & $31(54.4)$ & $20(42.55)$ & & $51(49.0)$ \\
\hline \multicolumn{5}{|l|}{ Pulp sensitivity $-n(\%) \neq$} \\
\hline Yes & $27(47.4)$ & $18(38.3)$ & 0.3528 & $45(43.3)$ \\
\hline No & $30(52.6)$ & $29(61.7)$ & & $59(56.7)$ \\
\hline \multicolumn{5}{|l|}{ Probing Depth (PD) - n (\%)‡ } \\
\hline$\leq 3 \mathrm{~mm}$ & $27(47.4)$ & $16(34)$ & 0.1696 & $43(41.3)$ \\
\hline $4-6 \mathrm{~mm}$ & $23(40.3)$ & $13(27.7)$ & 0.1758 & $36(34.6)$ \\
\hline$\geq 7 \mathrm{~mm}$ & $7(12.3)$ & $18(38.3)^{*}$ & 0.0020 & $25(24.1)$ \\
\hline$P D(m m)-M e a n\left(\right.$ Standard deviation) ${ }^{\varphi}$ & $4.29(2.25)$ & & $5.16(3.11)$ & \\
\hline
\end{tabular}

*Binomial test for two independent samples. ${ }^{\alpha}$ Binomial test for one sample. $\varphi$ Mann-Whitney for independent samples. ${ }^{*} \mathrm{P}<0.05$ was considered as a statistically significant difference.

Table 3. Frequency and diagnosis of the type of endodontic-periodontal lesion in non-molar and molar teeth

\begin{tabular}{|c|c|c|c|c|}
\hline \multirow{2}{*}{ Type of lesion } & \multirow{2}{*}{$\begin{array}{c}\text { Total frequency } \\
\text { N (\%) }\end{array}$} & \multicolumn{2}{|c|}{ Teeth- N (\%) } & \multirow{2}{*}{$P$ value } \\
\hline & & Non-molars & Molars & \\
\hline 1) Primary endodontic & $68(65.4)$ & $42(73.7)$ & $26(55.3)$ & 0.0501 \\
\hline $\begin{array}{l}\text { 2) Primary endodontic with secondary } \\
\text { periodontal involvement }\end{array}$ & $12(11.5)$ & $7(12.3)$ & $5(10.6)$ & 0.7942 \\
\hline 3) Primary periodontal & $6(5.8)$ & $4(7.0)$ & $2(4.3)$ & 0.5477 \\
\hline $\begin{array}{l}\text { 4) Primary periodontal with secondary } \\
\text { endodontic involvement }\end{array}$ & $5(4.8)$ & $1(1.7)$ & $4(8.5)$ & 0.1090 \\
\hline 5) True combined lesion & $13(12.5)$ & $3(5.3)$ & $10(21.3)^{*}$ & 0.0140 \\
\hline Total & $104(100)$ & $57(100)$ & $47(100)$ & \\
\hline
\end{tabular}

*Binomial test for independent samples (statistically significant difference; $\mathrm{p}<0.05$ ).

Table 4. Relationship between the total number of teeth $(n=104$, except for furcation bone rarefaction) and pulp vitality and clinical and radiographic characteristics

\begin{tabular}{ccccc}
\hline \multirow{2}{*}{ Variable } & & \multicolumn{2}{c}{ Pulp sensitivity N (\%) } & \multirow{2}{*}{ P value } \\
\cline { 3 - 4 } & & Yes & No & \\
\hline Proximal bone loss $(\mathrm{n}=104)^{\alpha}$ & Yes & $16(15.4)$ & $36(34.6)$ & 0.2311 \\
Furcation bone rarefaction in molars & No & $22(21.2)$ & $30(28.8)$ & \\
$(\mathrm{n}=47)^{\beta}$ & Yes & $2(4.3)$ & $15(31.9)$ & 0.2823 \\
Periapical pathology, radiographically & No & $9(19.1)$ & $21(44.7)$ & \\
visible $(\mathrm{n}=104)^{\beta}$ & Yes & $2(1.9)$ & $51(49.0)^{*}$ & 0.0000 \\
Probing Depth $(\mathrm{n}=104)^{\beta}$ & No & $36(34.6)$ & $15(14.5)$ & \\
& $\leq 3 \mathrm{~mm}$ & $20(19.2)$ & $23(22.1)$ & \multirow{2}{*}{0.1770} \\
\hline
\end{tabular}

${ }^{\alpha}$ Fisher's exact test. ${ }^{\beta}$ Chi-square test. ${ }^{*} \mathrm{P}<0.05$ indicates statistically significant difference.

\section{DISCUSSION}

The present study aimed to perform periodontal evaluations in teeth referred for endodontic treatment. The results showed that the majority of participants sought dental care due to the presence of pain (63.3\%), and the most frequently observed characteristics were caries/restorations (93.3\%) and the absence of pulp sensitivity (56.7\%). Moreover, considering 
the classification adopted ${ }^{2,4}$, it was found that $65.4 \%$ of the teeth presented a primary endodontic lesion.

On the other hand, it is important to highlight that primary and/or secondary periodontal pathologies were present in $34.6 \%$ of the evaluated teeth, suggesting that in some cases there was a concomitant occurrence of endodontic and periodontal lesions in the same tooth, requiring combined therapeutic procedures. Thus, it is worth noting that the periodontal problem also deserves attention during the endodontic clinical examination, considering that the majority of teeth presented bleeding on probing (68.3\%) and probing depth (PD) $\geq 4 \mathrm{~mm}(58.7 \%)$.

Another aspect to be considered was that the molar teeth presented significantly more PD $\geq 7$ $\mathrm{mm}(38.3 \%)$, as well as a higher mean probing depth $(6.17 \mathrm{~mm})$ than the non-molar teeth $(4.29$ $\mathrm{mm}$ ). Other factors to be considered in the molar teeth in relation to the non-molar teeth were the more significant prevalence of true combined lesion $(21.3 \%$ vs $5.3 \%)$, considering the classification adopted ${ }^{2,4}$.

Regarding the evaluation of pulp sensitivity and bone rarefaction in the furcation region of the molars, it was found that $31.9 \%$ of the sample presented negative pulp sensitivity and furcation rarefaction without increasing the horizontal probing depth, which is consistent with endodontic and not periodontal involvement. The presence of bone rarefaction in the furcation area in cases of pulp necrosis occurs due to the presence of accessory channels present in the furcation roof, capable of causing communication between the pulp and periodontium in this region ${ }^{11}$. According to some authors ${ }^{18}$, molars are the teeth that present more accessory canals compared to premolars and anterior teeth. The presence of bone rarefaction in furcation, although with normal height of bone ridges has been indicative of lesions of endodontic origin ${ }^{6}$. In addition, evidence demonstrates that endodontic molar infection has been associated with loss of insertion in the furcation area, with a mean insertion loss of $0.19 \mathrm{~mm} / \mathrm{year}$ in teeth with endodontic involvement compared with $0.06 \mathrm{~mm}$ in teeth without endodontic infection ${ }^{19}$ and may, if the infection is not treated, lead to the development of a combined endodontic-periodontal lesion.

The role of periodontitis progression in the pulp condition, characterizing primary periodontal involvement with secondary endodontic involvement is controversial. Some results have shown that the gradual progression of chronic periodontitis was able to lead to changes in the histopathological features of the root pulp ${ }^{20}$, while other findings showed that periodontal disease was able to make dental pulp respond negatively only in more advanced cases, when periodontitis reaches the dental apex and consequently the major apical foramen ${ }^{8,21}$. This explanation makes sense because the major foramen is the largest and has the greatest circulating blood supply, so if periodontal disease does not rupture the vascular-nerve bundles, the pulp has good prospects for survival21. In cases of combined periodontal and endodontic lesions, the prognosis is usually better in molar than in non-molar teeth, due to the possibility of performing alternative root resection techniques with greater loss of clinical insertion, maintaining the remaining roots ${ }^{18}$.

It is important to emphasize that endodontic treatment in a tooth with periodontal compromise can result in failure if periodontitis is not treated due to the communication pathways that may occur between pulp and periodontium, including via dentinal tubules ${ }^{9}$, accessory canals ${ }^{10}$, and canals located on the furcation roof 11 . In our findings, the presence of periapical lesion showed a significant relationship with the negative pulp response. It should also be noted that root canal infection, evidenced by the presence of periapical lesion/necrosis, may result in a long term delay or impairment in periodontal healing, i.e., the periapical pathology may prevent the healing of periodontal lesions, indicating that combined treatment strategies are essential for improving prognosis and preserving teeth ${ }^{22}$. Furthermore, some results indicate that if periodontal disease is not treated in combined endodontic/periodontal lesions, it may serve as a source of root canal infection, as there is similar, complex microbial diversity between the 
periodontal pocket and root canal, with the main species being Filifactor alocis, Parvimonas micra, Porphyromonas gingivalis, and Tannerella forsythia ${ }^{23}$.

Although radiographic examination has its limitations, it is an important device in determining endodontic-periodontal lesions. The radiographic evaluation showed that periapical pathology, furcation bone rarefaction, and proximal bone loss were present in 51\%, 36.2\%, 19.2\%, and $47.1 \%$ of the teeth, respectively. The presence of marginal bone loss associated with periapical lesions, seen radiographically, has been associated with alterations in endodontic origin over the periodontium, demonstrating greater bone loss in teeth with periapical lesions compared to those without lesions ${ }^{24,25}$, which demonstrates the importance of the relationship between endodontics and periodontics.

Randomized clinical studies with endodontic and periodontal lesions are difficult to perform and there are still few studies addressing this topic. Thus, it is suggested that other well-designed studies should be conducted, studying the different approaches to existing classifications, considering clinical, radiographic, and microbiological diagnostic criteria to better elucidate aspects related to the prognosis and treatment of these lesions.

\section{CONCLUSION}

The primary endodontic lesion was found in a greater proportion in teeth referred for endodontic treatment; however, approximately $1 / 3$ of the sample had periodontal involvement, which demonstrates the importance of the periodontal examination together with the general clinical examination.

\section{REFERENCES}

1. Papapanou PN, Sanz M, Buduneli N, Dietrich T, Feres M, Fine DH, et al. Periodontitis: consensus report of workgroup 2 of the 2017 world workshop on the classification of periodontal and peri-implant diseases and conditions. J Periodontol. 2018 Jun;89(Suppl. 1):S173-82. http://dx.doi.org/10.1002/JPER.17-0721. PMid:29926951.

2. Simon JH, Glick DH, Frank AL. The relationship of endodontic-periodontic lesions. J Periodontol. 1972 Apr;43(4):202-8. http://dx.doi.org/10.1902/jop.1972.43.4.202. PMid:4505605.

3. Armitage GC. Development of a classification system for periodontal diseases and conditions. Ann Periodontol. 1999 Dec;4(1):1-6. http://dx.doi.org/10.1902/annals.1999.4.1.1. PMid:10863370.

4. Simon JHS, Glick DH, Frank AL. The relationship of endodontic-periodontic lesions. J Endod. 2013 May;39(5):e41-6. http://dx.doi.org/10.1016/j.joen.2013.02.006. PMid:23611400.

5. Al-Fouzan KS. A new classification of endodontic-periodontal lesions. Int J Dent. 2014;2014:919173. http://dx.doi.org/10.1155/2014/919173. PMid:24829580.

6. Hirsch RS, Clarke NG. Pulpal disease and bursts of periodontal attachment loss. Int Endod J. 1993 Nov;26(6):362-8. http://dx.doi.org/10.1111/j.1365-2591.1993.tb00770.x. PMid:8144246.

7. Meng HX. Periodontic-endodontic lesions. Ann Periodontol. 1999 Dec;4(1):84-90. http://dx.doi.org/10.1902/annals.1999.4.1.84. PMid:10863379.

8. Neves VCQ, Toledo BEC, Camargo GACG, Souza AA, Zuza EP. Determination of the influence of chronic periodontitis on pulp sensibility by means of electric and thermal cold testing. J Endod. 2017 Nov;43(11):1802-5. http://dx.doi.org/10.1016/j.joen.2017.07.006. PMid:28951030.

9. Adriaens PA, Edwards CA, De Boever JA, Loesche WJ. Ultrastructural observations on bacterial invasion in cementum and radicular dentin of periodontally diseased human teeth. J Periodontol. 1988 Aug;59(8):493-503. http://dx.doi.org/10.1902/jop.1988.59.8.493. PMid:3171862. 
10. Rubach WC, Mitchell DF. Periodontal disease, accessory canals and pulp pathosis. J Periodontol. 1965 Jan-Feb;36(1):34-8. http://dx.doi.org/10.1902/jop.1965.36.1.34. PMid:14258503.

11. Zuza EP, Toledo BEC, Hetem S, Spolidorio LC, Mendes AJD, Rosetti EP. Prevalence of different types of accessory canals in the furcation area of third molars. J Periodontol. 2006 Oct;77(10):1755-61. http://dx.doi.org/10.1902/jop.2006.060112. PMid:17032120.

12. Matthews DC, Tabesh M. Detection of localized tooth-related factors that predispose to periodontal infections. Periodontol 2000. 2004;34(1):136-50. http://dx.doi.org/10.1046/j.09066713.2003.003429.x. PMid:14717860.

13. Angst PDM, Piccinin FB, Oppermann RV, Marcantonio RAC, Gomes SC. Response of molars and nonmolars to a strict supragingival control in periodontal patients. Braz Oral Res. 2013 Jan-Feb;27(1):5560. http://dx.doi.org/10.1590/S1806-83242013000100010. PMid:23306627.

14. Ainamo J, Bay I. Problems and proposals for recording gingivitis and plaque. Int Dent J. 1975 Dec;25(4):229-35. PMid:1058834.

15. Armitage GC. The complete periodontal examination. Periodontol 2000. 2004;34(1):22-33. http://dx.doi.org/10.1046/j.0906-6713.2002.003422.x. PMid:14717853.

16. Gjermo P, Bellini HT, Santos VP, Martins IG, Ferracyoli JR. Prevalence of bone loss in a group of Brazilian teenagers assessed on bite-wing radiographs. J Clin Periodontol. 1984 Feb;11(2):104-13. http://dx.doi.org/10.1111/j.1600-051X.1984.tb00838.x. PMid:6583209.

17. Aass AM, Rossow I, Preus HR, Gjermo P. Incidence of early periodontitis in a group of young individuals during 8 years: associations with selected potential predictors. J Periodontol. 1994 Sep;65(9):814-9. http://dx.doi.org/10.1902/jop.1994.65.9.814. PMid:7990016.

18. Rotstein I, Simon JHS. Diagnosis, prognosis and decision-making in the treatment of combined periodontal-endodontic lesions. Periodontol 2000. 2004;34(1):165-203. http://dx.doi.org/10.1046/j.0906-6713.2003.003431.x. PMid:14717862.

19. Jansson LE, Ehnevid H. The influence of endodontic infection on periodontal status in mandibular molars. J Periodontol. 1998 Dec;69(12):1392-6. http://dx.doi.org/10.1902/jop.1998.69.12.1392. PMid:9926769.

20. Zuza EP, Carrareto ALV, Lia RCC, Pires JR, Toledo BEC. histopathological features of dental pulp in teeth with different levels of chronic periodontitis severity. ISRN Dent. 2012;2012:271350. http://dx.doi.org/10.5402/2012/271350. PMid:22577568.

21. Langeland K, Rodrigues H, Dowden W. Periodontal disease, bacteria, and pulpal histopathology. Oral Surg Oral Med Oral Pathol. 1974 Feb;37(2):257-70. http://dx.doi.org/10.1016/0030-4220(74)904216. PMid:4520855.

22. Janssen LE, Ehnevid H, Lindskog SF, Blomlöf LB. Radiographic attachment in periodontitis-prone teeth with endodontic infection. J Periodontol. 1993 Oct;64(10):947-53. http://dx.doi.org/10.1902/jop.1993.64.10.947. PMid:8277402.

23. Li H, Guan R, Sun J, Hou B. Bacteria community study of combined periodontal-endodontic lesions using denaturing gradient gel electrophoresis and sequencing analysis. J Periodontol. 2014 Oct;85(10):1442-9. http://dx.doi.org/10.1902/jop.2014.130572. PMid:24579762.

24. Jansson L, Ehnevid H, Lindskog S, Blomlöf L. The influence of endodontic infection on progression of marginal bone loss in periodontitis. J Clin Periodontol. 1995 Oct;22(10):729-34. http://dx.doi.org/10.1111/j.1600-051X.1995.tb00254.x. PMid:8682918.

25. Miyashita H, Bergenholtz G, Gröndohl K, Wennström JL. Impact of endodontic conditions on marginal bone loss. J Periodontol. 1998 Feb;69(2):158-64. http://dx.doi.org/10.1902/jop.1998.69.2.158. PMid:9526914. 


\section{CONFLICTS OF INTERESTS}

The authors declare no conflicts of interest.

\section{*CORRESPONDING AUTHOR}

Elizangela Cruvinel Zuza, UFF - Universidade Federal Fluminense, Instituto de Saúde de Nova Friburgo, Programa de Pós-graduação em Odontologia, Rua. Dr. Silvio Henrique Braune, 22, 28625-650 Nova Friburgo - RJ, Brasil, e-mail: elizangelazuza@yahoo.com.br

Received: July 21, 2021

Accepted: September 1, 2021 